\title{
THE POSSIBILITIES AND THE PRACTICE TO PROTECT THE PUBLIC AND THE STATE'S FISCAL INTEREST BY THE CONSTITUTIONAL TRIBUNAL
}

\author{
PIOTR WOLTANOWSKI ${ }^{1}$ RÓŻA KOSIŃSKA ${ }^{2}$
}

\begin{abstract}
According to the Authors opinion in this paper's, sometimes undertaken practice of the judgments regarding the tax law relationship conducted by the Constitutional Tribunal to specify the public interest in opposition to the entity rights and by bringing the need to respect the State Treasury and to achieve the planned revenue for the budget, cannot be approved. State's fiscal interest justified by the CT case is contrary to the public interest: retroactivity, the legislation ambiguity and lack of the respect to the established right. At the same time, there is underlying the need to provide for the tax legislator certain freedom while creating tax policy. The Tribunal should strive to balance the protection of the individual and social interest as well as to protect the interests of the single participants in the economic life. The CT should continue issue interpretative judgments - it is a valuable tool in the efforts to ensure an appropriate level to protect the individual and public interest, but it should accuse the current practice of issuing application judgments.
\end{abstract}

\section{Keywords}

State's Treasure Interest; fiscal interest; State's interest; budget interest; taxpayers' rights

\section{JEL Classification: K10, K34, H0O}

1 Board Member and General Secretary of Information and Organization Centre for the Research on the Public Finances and Tax Law in the Countries of Central and Eastern Europe, Department of Public Finances and Financial Law, Faculty of Law, University of Bialystok. He is the author of over 50 publications in the field of tax administration, human rights, health service finance and social security. Contact email: piotrwoltanowski@ gmail.com.

2 Member of the Audit Committee of Information and Organization Centre for the Research on the Public Finances and Tax Law in the Countries of Central and Eastern Europe, Secretary of Drohiczyn Scientific Society. An experienced practitioner of economics, a long-standing employee of the tax apparatus, an external and internal risk analyst, author of many publications in the field of tax administration. Contact email: rozmark@wp.pl. 


\section{Introduction}

The need to protect the public interest is the essential value emphasized by the Constitutional Tribunal in the tribute paid case law. The analysis of the objective scope in the polish constitutional court's case law practice, cause some anxiety regarding the inconsistency of the used terminology: the Tribunal seems to identify the constitutional value and the needs to achieve the planned budgetary revenue all together with the State's Treasure interest, fiscal interest, the State's interest, budget interest, as well as with the public interest. As a consequence, The Polish Constitutional Court seems to use the interchangeable terminology with the similar and interlocking meaning but with the different significance for the public interest as:

- State's Treasury interest (Constitutional Tribunal: W.12/92);

- State's fiscal interest (Constitutional Tribunal: K.4/03; Constitutional Tribunal: P.90/08 ; Constitutional Tribunal: K.21/14);

- Keeping the public finance balance interest (Constitutional Tribunal: K.21/14);

- State's interest (Constitutional Tribunal: W.3/94; Constitutional Tribunal: K.22/96; Constitutional Tribunal: K.23/98; Constitutional Tribunal: K.11/98; Constitutional Tribunal: P.9/15);

- Budget interest (Constitutional Tribunal: K.16/07);

- General interest (Constitutional Tribunal: W.3/94);

- Social interest (Constitutional Tribunal: P.9/15; Constitutional Tribunal: U.5/86; Constitutional Tribunal: W.1/89; Constitutional Tribunal: W.3/93; Constitutional Tribunal: W.8/93);

- National interest (Constitutional Tribunal: K.22/96; Constitutional Tribunal: U.24/97; Constitutional Tribunal: K.11/98).

The Tribunal, in his case law, respects the need to protect the local government authority interest (Constitutional Tribunal: W.12/92) as well as the municipality interest (Constitutional Tribunal: K.27/95). In terms of the public interest, and above all the fiscal interest, the Constitutional Tribunal mentioned also about the fiscal justice and the general obligation of the taxes liability. In this way, together with the observed chaos, within the used terminology, we are facing the worrying phenomena provided by the polish ombudsman, where "the general legal rules recognition in terms of the collective nature, which so far cannot be apportioned between the similar set of certain values - the dangerous phenomenon, which is leading to underline the recognition of the nature of the individual goods" (Ombudsman of Citizens' Rights: II.501.4.2017.MH). 
This paper refers to the Tribunal law case study, which actually equates to the fiscal (as the budget interest within the lax law relationship) and public interest. Such simplification of the complicated dependency between the two values are worrying - there for more, the CT withstand the unit of values regarding the fiscal interest (called "the public interest") with the values related to the taxpayers interest, the groups of taxpayers (e. g. consumers, disabled persons or most often entrepreneurs) or even legitimate the interest of citizens (Constitutional Tribunal: P.9/15). Only several situations can be listed as the limited exemptions, where the CT clearly distinguish (or even oppose) public and fiscal interest (Constitutional Tribunal: SK.35/14; Constitutional Tribunal: P.41/10).

It seems, that the Tribunal could more often implicate the situations in the case law, where the interest of the taxpayers coincide (e.g. by establishing the law of the sufficient quality) with the public interest (not necessarily with the state's fiscal interest). The study development may consider to the equation of the public interest with the practice of the democratic state based on the rule of law (as described in the case law) than maximizing the budget financial needs. The relevant approach to the scope of the public interest could give the appropriate range for the key constitutional values, e.g. correct tax legislation, which would enhance the protection of the taxpayer interest. There would not be anything new, especially, if we look at the ECHR case law practice, which combines different aspects of the rule of law and the implementation of the public interest.

\section{Limits Public and Fiscal Interest Protection in Case Law of Constitutional Tribunal}

Particularly, there is the apparent importance of the fiscal interest, if we consider the principles relevance and obvious, which could be in some way "faced" in the CT case law. We are writing about the fundamental and proper taxes rules, which often are violated by the taxation legislator (Woltanowski, 2012: 530).

The public interest in the Tribunal judgments regarding the tax law relationship relates first of all to the need to ensure the budget revenues at an appropriate level (Constitutional Tribunal: SK.23/03). For this reason "Constitutional Tribunal accept permissible possibility for the legislative reduce the rights of the individuals public property due to the public interest and (...) the barriers of the state's capability to execute, which are common goods" (the article 1 of the Constitution) and due to (...) the state's ability to assume it fundamental obligations" (Constitutional Tribunal: K.2/04). 
The scope, where these values can limit the rights and freedoms is determined by the specific nature of the individual rights and the entity freedom, and above all, by the principle of proportionality. In the Tribunal opinion "the principle of the proportionality is the constituent component of the rule of law. The rule of law is based on the assumption of the rationality of the legislator, and a prerequisite for the assumption is compliance with proportionality in the law-making process.

The rational legislator provide the right justice, hence, in principle, it should also be seen as the base of the principle of proportionality" (Constitutional Tribunal: K.9/95). Against this background, it should be recalled, that in the Tribunal opinion "the harsher standards and the examination should be applied to the law regulations and the personal and political freedom, rather than to the economic or social rights" (Constitutional Tribunal: U.3/96). In the case law of the Constitutional Tribunal regarding the tax law, the issue of the protection limits the right of the taxpayers are closely related to the legislator compliance with the principle of proportionality, which is expressed in the Art. 31/3 of the Constitution of the Republic of Poland.

Polish Constitutional Court underlined, that the rank of the public interest contains enumerated objectives, which are prescribed in the article 31 paragraph 3. In fact, they are the tasks for the public authority to be able to limit legal constitutional rights and freedom within the analyzed context. In this regard, by providing the appropriate financial funds to the state's budgetary for implementing these tasks is one of the necessary conditions to pursue the public interest. The scope of policy jurisdiction, formed by the Constitutional Tribunal and initiated by the decision given on 26 May 1995 (Constitutional Tribunal: SK.11/94), where previously occurred propositions have been generalized in the case law of the Tribunal, are unified and consistent.

The Tribunal recognises the values of the public interest, which often are in a conflict with the "group interests" (Constitutional Tribunal: K.22/96) and "the interests of the individual" (Constitutional Tribunal: K.11/98) and having guarantee nature as proper legislation, justice, equality, property protection, a closed catalog of the law sources and the statutory definition of the tax construction components (Woltanowski, 2005: 60).

This is a very narrow approach, which does not take into account the interests of a significant group of people, who are interested in a wider redistribution, rather than the protection of the taxpayers' rights. Additionally, the term of the public interest, also in the field of the tax issues, does not completely equal to the term of the state interest, or even more, with the "the state's fiscal interest", where is often identified with (Constitutional Tribunal: K.22/96). It seems, that such terminological inconsistency should not take place - especially regarding the 
The Possibilities and the Practice to Protect the Public and the State's Fiscal Interest...

presented in the CT case law, where are opposing the interests of the commune (or territorial self-government authorities) - with the state's interest (Constitutional Tribunal: W.12/92).

It is also worth to raise, that despite emphases in this context (Constitutional Tribunal: SK.23/01) the content of the Art. 1 of the Constitution, whereby the Republic of Poland is the common good of all citizens, even in the state formal legitimacy, but also with the contrary needs of the community. Perceiving the classification of "the state interest" as sui generis the sum of the individual entities seems to be also the serious simplification - especially when we will take into the account the contradictions proceed within them (Woltanowski, 2005: 60). There is arising anxiousness regarding the reduction of the material scope meaning to the need to ensure the state budget revenues at the planned level (Woltanowski, 2012: 531).

The public interest in the CT case law regarding the taxes can be interpreted as the ratio legis by establishing the obligation of the levy (Constitutional Tribunal: P.6/02; Constitutional Tribunal: K.2/03) or as the fiscal interest of the regulatory relationships (Constitutional Tribunal: K.2/94; Constitutional Tribunal: K.9/92; Constitutional Tribunal: P.4/98; Constitutional Tribunal: K.4/03; Constitutional Tribunal: K.8/03).

\section{Fiscal Interest and Non Retroactivity of Tax Law in terms to Need to Protect Public Interest}

The need to protect the budgetary revenues on the planned level forms usually justification to withdraw from the fundamental rights execution and the taxpayers' rights as well as the state's democratic order protection by the Tribunal - thereby the public interest - the principles of the proper legislation, by including the principles of the non-retroactivity of the tax law.

The Polish Constitutional Court declares, that the retro action is reasonable, when the law regulation seeks to remove the effects of the activities, which aims to be nefarious or seeks to evade the law (Constitutional Tribunal: U.10/89; Constitutional Tribunal: K.3/91; Constitutional Tribunal: K.8/94; Constitutional Tribunal: K.13/94). However, in practice, such approach is justified in the situations, where the legislator rectifies his own previous the legislative mistakes, which can affect on the effective law circumvention. That approach can be hardly acceptable, especially, when it based on the tax nature, where the need of strengthening the law is essential. It should be mentioned, that this solution's offer is the convenient path to correct the legislative mistakes without any Constitutional Tribunal objection. 
Unfortunately, it seems to be particularly tempting nowadays, by representing the comfortable (although deceptive) alternative to the laborious process of the proper creation of the tax law.

\section{Fiscal Interest and Need to Maintain relevant Vacation Legis in terms to Protect Public Interest}

The obligation to keep the reasonable long vacatio legis provides the equitable implementation (similar to the principle of non-retroactivity) of the public interest. Regarding this, it is possible to:

- introduce the amendments of the rules to the recipients (taxpayers) which may come into the force;

- protect the taxpayers' interest in the ongoing process;

- prevent the legislative authority abuse towards citizens.

According to the extensive case law of the Tribunal and by examining the accuracy of the length of the period of vacatio legis, takes into the consideration, inter alia:

- the nature and substance of the new regulations (Constitutional Tribunal: K.1/94);

- the social importance of the new regulations (Constitutional Tribunal: K.1/94);

- regulations wideness, which may come into the force (Constitutional Tribunal: K.1/94);

- the need to provide for the entrepreneurial taxpayer's particular assurances of legal security (Constitutional Tribunal: K.9/92; Constitutional Tribunal: K.8/93).

Regarding the proper evaluation of vacatio legis, the Tribunal in the case law uses the term "public interest" in relation to the legislator activities, which aim is defying the frauds and the taxation malfeasance (Constitutional Tribunal: K.2/94) and even can validate the back down from the established period of vacatio legis (Constitutional Tribunal: K.9/94). In this case, the public interest somehow can be reduced - as in the previously mentioned case (Constitutional Tribunal: K.2/94), where arises the need to ensure the achieving State's budgetary incomes.

Particularly, we can be worried about, when we will remind, that in the Tribunal opinion, generally, if the taxation issues saved 14 days adjustment period, violation of the Art. 2 of the Constitution can succeed barely - only in the conspicuous cases (Constitutional Tribunal: K.55/02). It seems, that we are dealing with the situation, 
in which the public interest is to understand extremely narrowly and reduced to the current fiscal interest only. The Tribunal seems to allow for the legislator too big freedom in the imperious interference of the taxpayer's property area (Constitutional Tribunal: K.57/13). Obviously, it is possible to imagine exceptional situations, as war or large-scale natural disaster, in connection, where the omission of the adjustment period will be indicated indeed and compatible with the public interest. However, the current amendments brought by the incompetent legislator to the previously adopted legal norms do not deserve such justification. According to the Authors' opinion of this article, they arise as the result of irregularities in the earlier legislative process, and not appear in the expression of the legislator attention (or the Polish Constitutional Court) to the public interest.

\section{Practice to Amend the Changes into Legal Acts in the period of their Vacatio Legis in terms to Protect Public Interest}

Changes introduced in this mode reduce the authority of the legislator body, destroy the taxpayers' security regarding the sense of legal certainty and, above all, make it impossible to adapt to the content of the new regulations (Woltanowski, 2012: 537). The act adopted by the parliament in the prescribed mode, signed by the President and announced in the "Journal of Laws", created among the potential recipients of the law the conviction and at the same time the expectation, that the adopted legislation in its original form will come into the force within the specified by that act period (Constitutional Tribunal: K.12/03).

Unfortunately, the Constitutional Tribunal accepts the revision of the legal act in the period of coming into the force in the two cases only by:

1. revising the mistakes, internal inconsistency or solutions, which leads to the incompatibility of the law system after the adoption of the normative act,

2. preventing the negative effects (especially fiscal consequences) of the adopted regulations coming into force of the adopted, but not applicable yet (Constitutional Tribunal: K.12/03).

In the Authors' opinion, such practice cannot be justified. In both presented cases above, should not be accepted the reduction of the fundamental rights of the public interest ( and the protection of the individual interest) in terms of the legal certainty. The relevant shares of budgets are possible to collect without destroying the foundation of the legal state. 


\section{Protection of Established Rights in terms of Tax Law Relationship Regulations and Public Interest}

It seems that emphasized the relative freedom of the legislator in terms of the tax law by the Tribunal in the case law (Constitutional Tribunal: K.1/95), rationally limits the scope of the public interest protection in favor for the common interest. The Constitutional Tribunal emphasizes the power of the legislator authority regarding the lawmaking in accordance with the assumed political and economic objectives (Constitutional Tribunal: K.7/93) and together implement the tax policy based on the principle of the social solidarity of the tax policy, in terms of the public interest. In the Constitutional Tribunal opinion, as far, the changes of the construction of the individual taxes, including the maintain or withdraw of the tax exemptions by the legislator promotes presumptive relative regulatory freedom (Constitutional Tribunal: K.6/02).

However, it should be strongly emphasized, that the Tribunal should rather endeavor the principle of protection of the established rights nor with the public or (mostly direct) fiscal interest, but with the principle of the prevalence of taxation, under the Art. 84 of the Constitution (Woltanowski, 2012: 541).

\section{Protection of State's Fiscal Interest and Practice to Issue so-called Interpretative and Application Judgments by Constitutional Tribunal}

The violation of the constitutional requirements about the clarification and the proper communications of the legal text, which are unclear and inaccurate in terms of formulating the rule, and affects the recipients' fragility regarding their rights and responsibilities at the same time create the legal trap for the citizen (Constitutional Tribunal: K.13/93; Constitutional Tribunal: K.1/94). Breaking that rule leads to use the extended interpretation by the fiscal authorities (Kosińska, Ruśkowski, Woltanowski, 2016: 533) and their activities can occur for example, through:

- the lack of ability for the conclusive statement regarding the structural components of the taxes;

- the multiple interpretations and the rules use, due to the lack of legislator precision in this terms;

- the extended scope of using the tax law relationship rules among the entities range in an inappropriate manner due to the earlier purpose of the legislator (Constitutional Tribunal: K.33/02; Constitutional Tribunal: K.44/07; Constitutional Tribunal: K.28/02; Constitutional Tribunal: 
The Possibilities and the Practice to Protect the Public and the State's Fiscal Interest...

K.45/02; Constitutional Tribunal: K.31/10; Constitutional Tribunal: K.33/05; Constitutional Tribunal: K.4/06; Constitutional Tribunal: P.28/07; Constitutional Tribunal: K.32/03; Constitutional Tribunal: K.4/09; Constitutional Tribunal: K.1/05; Constitutional Tribunal: SK.51/05; Constitutional Tribunal: K.21/05; Constitutional Tribunal: SK.96/06; Constitutional Tribunal: SK.17/07; Constitutional Tribunal: SK.64/08; Constitutional Tribunal: K.1/10).

Straightforward elimination of the nonprecious and unclear regulations for the overall recipients from the existing law by the Tribunal, can be tough in judgment practice, due to the negative consequence for the judgment regarding the budgetary revenues or for the whole system of the rules of the tax law. Protecting the fiscal interest - however, in the Authors opinion, the public interest also, the CT issues the interpretative judgments, which (optionally):

- recognise the provision to be incompatible in a specific - subjective, objective or temporal scope of its implementation;

- recognise the provision as an incompatible under the condition of its proper understanding (Woltanowski, 2012: 533).

The Polish Constitutional Court, by publishing that kind of judgments, expose himself for the allegation regarding the existing general law interpretation (that could be the attack of the judiciary independence through the binding the judiciary by the courts' given interpretation) or through the activity of the lawmaking. However, for the opponents of this scope of the CT activity, can point the presumption of constitutionality and the hierarchically lower acts legality, as the purposefulness of law enforcement by the Constitutional Tribunal, and the principle of legal certainty and formulation of the content under Art. 190 of the Constitution.

Published the interpretative judgments are certainly compatible with the public interest through:

- the strengthening the legal certainty and by the clarifying the non-restrictive tax law regulations;

- the reducing the vulnerability of the appearing gaps', which arises as the result of the removal the unconstitutional regulations from the legal circulation;

- the possibility to influence the doctrines of law in force additionally;

- the respectively deliberated balance between the protection of the taxpayer's rights and the state's fiscal interest.

There is no possible to agree with the practice of given application judgments. The CT within the framework decides regarding the scope of the influence of 
the unconstitutional provision on the social relations, i.e. based on the activities performed in the past. Application judgments are particularly often issued in the area of tax law - for example the CT concluded, that the tax or payment paid due to the noncompliant rules of the constitutional law is non-refundable (Constitutional Tribunal: P.7/00; Constitutional Tribunal: P.6/02). It seems, that issuing such judgments beyond the scope of constitutional competence of the Constitutional Tribunal cannot be reconciled with the base function of the Constitutional Tribunal, which is just monitoring the legislation. However, the Tribunal conclude, that it is not only entitled to adjudicate on non-conformity of the normative acts with the Constitution, but also has the authority to determine the temporal framework of such inconsistency, especially the time limits of the retrospective scope of the judgments which determine incompatibility with the Constitution described in the specific provision (legal norm). The argument, provided under the Art. 190/3 of the Constitution, gives the possibility to postpone the date of binding the force for the normative act. The CT derives the conclusion from that provision, that it is able to determine the more extended scope for the retrospective coverage as well as the effects on its given judgments (Constitutional Tribunal: K.24/03). It seems, that such arguments is not justified due to the lack of clear connection between the competence truly given to the Tribunal and the usurped authority.

\section{Conclusions}

The Constitutional Tribunal, by examining, the subject of the compatibility with the constitutional applicable measures to protect the state's fiscal interest uses three main criterion:

- the criterion of the purpose limitation;

- the criterion of the proportionality;

- the criterion of the usefulness (Constitutional Tribunal: SK.33/03; Constitutional Tribunal: SK.23/01; Ombudsman of Citizens' Rights: II.501.4.2017.MH).

The first listed - the criterion of the purpose limitation refers to the rank of probability to implement the assumed effects by the legislator on the monitoring regulation The used tools to protect the public interest are inspecting in regards to their applicable necessity (the criterion of the usefulness). There is also examined issue of the proportionality of regulation's effectiveness through their imposed liabilities.

The specific "axiological measured" need to protect the fiscal and individual interest handles the central role in the case law of the Constitutional Tribunal regarding the 
tax law. However, in several judgments regarding that range, the $\mathrm{CT}$ recognizes also the scope, where is the need to ensure the budget revenues on the appropriate level and the need to protect the taxpayer's rights, which are not contrary, but are identical. As an example, there can be the need to maintain the budget balance, which considers as the constitutional value by the Tribunal. That value, emphasized many times in the case law, maintain the state's and the local self - governments authorities ability to act and solve multiple public needs (Constitutional Tribunal: K.27/98; Constitutional Tribunal: K.13/01; Constitutional Tribunal: K.6/02). The big part of the taxpayers appears also directly (or maybe first of all) as the beneficiary of the public funds by receiving from the state's budget salaries, retirements, and other supplied benefits. The need to protect that individuals interests influence the direction of understanding the proper meaning (in some way by the Tribunal too) of the public interest.

There will be difficult not to agree with the Commissioner for the Human Rights conclusions, who in his application to the Tribunal ask to examine a number of proposed solutions in the law of the National Revenue Administration, in which is described, that "it is impossible to maintain the trusted and loyal relationship [essential from the point of view of the public interest], if the state forms its competences in seriously interfering way with the freedom and citizens' rights, without indicating the limits of the benefiting from these competences, or setting the limits beyond the principle of proportionality" (Ombudsman of Citizens' Rights: II.501.4.2017.MH). However, the public interest requires the effective and the fully implemented law - as the fundamental aspect of the state's presence - that is why the fight against his violations (unless the used tools do not reconcile to the violate the basic principles of the democratic state of the law) pursues the public interest.

Furthermore, fiscal frauds together with the loans extortion, dishonest business management, "money laundering" strike not only to the budget financial security but also to the subject interest, which performs the honest and legitimate economic activity. Performing the tax-free economic activity by the same subjects in a same scope of the operations under the free market competitions can affect on the elimination those subject from the economic turnover, whom reliably fulfill their tax obligations. The CT underline, that, "if in polish economic reality exist "the shadow zone", when the legislator has the right and even the responsibility to adopt the regulations, which eliminate it", (Constitutional Tribunal: SK.11/94) and also "recognize the presence of the substantial public interest, where established regulations are using for the purpose to protect not only the state interest but also those economic subjects, who wish to carry out their activity in the honest and legal way" (Constitutional Tribunal: SK.11/94). 


\section{References}

Kosińska, R., Ruśkowski, E., Woltanowski, P.: Effectiveness of tax services during the reformation period - selected issues (Efektywność służb podatkowych w okresie ich reformowania wybrane zagadnienia), Finanse, Rynki Finansowe, Ubezpieczenia (Finances, Financial Markets, Insurances) no. 6 (2016), DOI: 10.18276/frfu.2016.6.84/2-02.

Woltanowski, P.: Category of public interest in Constitutional Court jurisdiction in tax cases, in: Štrkolec, M.: Current questions of the efficiency of public finance, financial law and tax law in the countries of Central and Eastern Europe, Košice: Pavol Jozef Šafárik University in Košice, 2005.

Woltanowski, P.: Zasady prawidłowej legislacji podatkowej, a ochrona interesu Skarbu Państwa w orzecznictwie Trybunału Konstytucyjnego (The principle of proper tax legislation and protection of the interest of the State Treasury in the jurisprudence of the Constitutional Court), in: Etel, L., Tyniewicki, M. (eds.): Księga jubileuszowa profesora Eugeniusza Ruśkowskiego (Anniversary book of Professor Eugeniusz Ruśkowski), Bialystok: Temida 2, 2012.

PL: Constitutional Tribunal: P.9/15.

PL: Constitutional Tribunal: K.21/14.

PL: Constitutional Tribunal: K.57/13.

PL: Constitutional Tribunal: K.31/10.

PL: Constitutional Tribunal: K.1/10.

PL: Constitutional Tribunal: K.4/09.

PL: Constitutional Tribunal: SK.64/08.

PL: Constitutional Tribunal: P.90/08.

PL: Constitutional Tribunal: SK.17/07.

PL: Constitutional Tribunal: K.16/07.

PL: Constitutional Tribunal: P.28/07.

PL: Constitutional Tribunal: K.44/07.

PL: Constitutional Tribunal: K.4/06.

PL: Constitutional Tribunal: SK.96/06.

PL: Constitutional Tribunal: K.1/05.

PL: Constitutional Tribunal: K.21/05.

PL: Constitutional Tribunal: K.33/05.

PL: Constitutional Tribunal: SK.51/05. 
PL: Constitutional Tribunal: K.2/03.

PL: Constitutional Tribunal: K.12/03.

PL: Constitutional Tribunal: K.32/03.

PL: Constitutional Tribunal: K.8/03.

PL: Constitutional Tribunal: K.4/03.

PL: Constitutional Tribunal: SK.23/03.

PL: Constitutional Tribunal: K.45/02.

PL: Constitutional Tribunal: K.33/02.

PL: Constitutional Tribunal: K.6/02.

PL: Constitutional Tribunal: K.28/02.

PL: Constitutional Tribunal: P.6/02.

PL: Constitutional Tribunal: SK.23/01.

PL: Constitutional Tribunal: K.13/01.

PL: Constitutional Tribunal: P.7/00.

PL: Constitutional Tribunal: K.11/98.

PL: Constitutional Tribunal: K.23/98.

PL: Constitutional Tribunal: K.27/98.

PL: Constitutional Tribunal: P.4/98.

PL: Constitutional Tribunal: U.24/97.

PL: Constitutional Tribunal: K.22/96.

PL: Constitutional Tribunal: K.27/95.

PL: Constitutional Tribunal: K.13/94.

PL: Constitutional Tribunal: K.2/94.

PL: Constitutional Tribunal: K.8/94.

PL: Constitutional Tribunal: W.3/94.

PL: Constitutional Tribunal: W.3/93.

PL: Constitutional Tribunal: W.8/93.

PL: Constitutional Tribunal: K.8/93. 
PL: Constitutional Tribunal: W.12/92.

PL: Constitutional Tribunal: K.9/92.

PL: Constitutional Tribunal: K.3/91.

PL: Constitutional Tribunal: W.1/89.

PL: Constitutional Tribunal: U.10/89.

PL: Constitutional Tribunal: U.5/86.

PL: Ombudsman of Citizens' Rights: II.501.4.2017.MH, 